\title{
ÁlbuM DE FOTOGRAFÍAS QUE NO TOMÉ
}

\author{
Isabel Zapata*
}

\begin{abstract}
1.
El cielo pálido de la Ciudad de México.

Mi padre convertido en su propia sombra, intentando atrapar aire con las manos. ¿Qué ven los desahuciados que los hace moverse así?

Nosotros quietos, frotando los minutos para sacarles brillo.
\end{abstract}

2.

El sacerdote lleva puestos unos mocasines de lujo mientras unta la frente de mi padre con aceite de invierno.

\section{3.}

El amarillo es el color de los finales: mira las uñas de un moribundo.

\section{4.}

Después de una vida de delgadez, tiene el estómago hinchado de sangre sucia.

Por momentos se avergüenza y se cubre a medias con la sábana.

* Isabel Zapata (Ciudad de México, 1984) estudió Ciencia Política en el ITAM y Filosofía en la New School for Social Research de Nueva York. Escribe, traduce y edita. Es fundadora de Ediciones Antílope. 


\section{5.}

Su hígado:

una granada madura que se abre.

6.

Quemamos su cuerpo y las seis letras de su nombre de madera.

El bosque de Tlalpan salpicado de sus cenizas blancas: junto a la virgen el letrero no pisar el césped que todos estábamos pisando.

7.

Los muertos se extienden sobre el mundo, nosotros también nos extendimos

tocamos las plantas

con los dedos polvosos.

8.

Estamos todos pero la casa está vacía.

Hay un río en el espacio que ocupaba la casa.

Me siento a la orilla y miro a mi padre convertirse en un fantasma azul sobre las sábanas de agua. 